\title{
ADORA3 Gene
}

National Cancer Institute

\section{Source}

National Cancer Institute. ADORA3 Gene. NCI Thesaurus. Code C38615.

This gene is involved in ischemic cellular protection and G protein-coupled receptor signal transduction. 